15 Morrison AP, Renton JC, Dunn H, Williams S, Bentall RP. Cognitive Therapy for Psychosis: A Formulation-Based Approach. Brunner-Routledge, 2004.

16 Newman CF, Leahy RL, Beck AT, Reilly-Harrington NA, Gyulai L. Bipolar Disorder: A Cognitive Therapy Approach. American Psychological Association, 2002.

17 Rosenberg SD, Mueser KT, Jankowski MK, Salyers MP, Acker K. Cognitive-behavioral treatment of posttraumatic stress disorder in severe mental illness: results of a pilot study. Am J Psychiatr Rehab 2004; 7: 171-86.

18 Lu W, Fite R, Kim E, Hyer L, Yanos PT, Mueser KT, et al. Cognitive-behavioral treatment of PTSD in severe mental illness: pilot study replication in an ethnically diverse population. Am J Psychiatr Rehab 2009; 12: 73-91.

19 Mueser KT, Rosenberg SR, Xie H, Jankowski MK, Bolton EE, Lu W, et al. A randomized controlled trial of cognitive-behavioral treatment of posttraumatic stress disorder in severe mental illness. J Consult Clin Psychol 2008; 76: 259-71.

20 Plante TG. Contemporary Clinical Psychology. Wiley, 2011.

21 Wampold BE. The Great Psychotherapy Debate: Models, Methods, and Findings. Lawrence Erlbaum Associates, 2001.

22 American Psychiatric Association. Diagnostic and Statistical Manual of Mental Disorder (4th edn) (DSM-IV). APA, 1994

23 First MB, Spitzer RL, Gibbon M, Williams JBW. Structured Clinical Interview for DSM-IV Axis-I Disorders - Patient Edition (SCID-I/P, Version 2.0). Biometrics Research Department, New York State Psychiatric Institute, 1996.

24 Gearon JS, Bellack AS, Tenhula WN. Preliminary reliability and validity of the Clinician-Administered PTSD Scale for schizophrenia. J Consult Clin Psychol 2004; 72: 121-5

25 Weathers FW, Ruscio AM, Keane TM. Psychometric properties of nine scoring rules for the Clinician-Administered Posttraumatic Stress Disorder Scale. Psychol Assess 1999; 11: 124-33.

26 Kubany ES, Haynes SN, Leisen MB, Owens JA, Kaplan AS, Watson SB, et al. Development and preliminary validation of a brief broad-spectrum measure of trauma exposure: the Traumatic Life Events Questionnaire. Psychol Assess 2000; 12: 210-24.

27 Blanchard EP, Jones-Alexander J, Buckley TC, Forneris CA. Psychometric properties of the PTSD Checklist. Behav Ther 1996; 34: 669-73.

28 First MB, Spitzer RL, Gibbon M, Williams JBW, Benjamin L. Structured Clinical Interview for DSM-IV Axis-II Personality Disorders (SCID-II) (Version 2.0). Biometrics Research Department, New York State Psychiatric Institute, 1994.

29 Kay SR, Opler LA, Fiszbein A. The Positive and Negative Syndrome Scale (PANSS) for schizophrenia. Schizophr Bull 1987; 13: 261-76.

30 Lehman A, Kernan E, Postrado L. Toolkit for Evaluating Quality of Life for Persons with Severe Mental Illness. The Evaluation Center at HSRI, 1995.
31 Jones SH, Thornicroft G, Coffey M, Dunn G. A brief mental health outcome scale-reliability and validity of the Global Assessment of Functioning (GAF). Br J Psychiatry 1995; 166: 654-9.

32 Pratt SI, Rosenberg SD, Mueser KT, Brancato J, Salyers MP, Jankowski MK, et al. Evaluation of a PTSD psychoeducational program for psychiatric inpatients. J Mental Health 2005; 14: 121-7.

33 Foa EB, Ehlers A, Clark DM, Tolin DF, Orsillo SM. The Posttraumatic Cognitions Inventory (PTCI): development and validation. Psychol Assess 1999; 11: 303-14.

34 Beck AT, Steer RA, Brown GK. Manual for the Beck Depression Inventory-II. Psychological Corporation, 1996.

35 Beck AT, Steer RA. The Beck Anxiety Inventory Manual. Psychological Corporation, 1993.

36 Mueser KT, Fite R, Rosenberg SD, Gottlieb JD. Brief PTSD Treatment Program Dartmouth Psychiatric Research Center, 2008.

37 Ehlers A, Clark DM. A cognitive model of posttraumatic stress disorder. Behav Res Ther 2000; 38: 319-45.

38 Horowitz MJ. Stress Response Syndromes. Jason Aronson, 1986

39 Lu W, Yanos PT, Gottlieb JD, Duva SM, Silverstein SM, Xie H, et al. Using fidelity assessments to train clinicians in the CBT for PTSD program for clients with serious mental illness. Psychiatr Serv 2012; 63: 785-92.

40 Hedeker D, Gibbons RD. Longitudinal Data Analysis. Wiley, 2006.

41 Lipsey MW. Design Sensitivity: Statistical Power for Experimental Research. Sage, 1990.

42 Ehlers A, Clark DM, Hackmann A, McManus F, Fennell M, Herbert C, et al A randomized controlled trial of cognitive therapy, a self-help booklet, and repeated assessments as early interventions for posttraumatic stress disorder. Arch Gen Psychiatry 2003; 60: 1024-32.

43 Ehlers A, Hackmann A, Grey N, Wild J, Liness S, Albert I, et al. A randomized controlled trial of 7-day intensive and standard weekly cognitive therapy for PTSD and emotion-focused supportive therapy. Am J Psychiatry 2014; 171: 294-304.

44 Resick PA, Nishith P, Weaver TL, Astin MC, Feuer CA. A comparison of cognitive processing therapy with prolonged exposure and a waiting condition for the treatment of posttraumatic stress disorder in female rape victims. J Consult Clin Psychol 2002; 70: 867-79.

45 Katon W, Von Korff M, Lin E, Simon G, Walker E, Unützer J, et al. Stepped collaborative care for primary care patients with persistent symptoms of depression: a randomized trial. Arch Gen Psychiatry 1999; 56: 1109-15.

46 Zatzick D, Rivara F, Jurkovich G, Russo J, Trusz SG, Wang J, et al. Enhancing the population impact of collaborative care interventions: mixed method development and implementation of stepped care targeting posttraumatic stress disorder and related comorbidities after acute trauma. Gen Hosp Psychiatry 2011; 33: 123-34.

\title{
Psychosocial aspects of addiction
}

\section{Ken Checinski}

Psychosocial interventions for substance misusers are diverse, with NICE guidance supporting brief interventions (particularly for alcohol), self-help (e.g. AA, NA and SMART Recovery) and contingency management (including supporting families) in particular Often, recovery involves the unpicking and reshaping of complex behavioural patterns, social and family networks and the effective treatment of mental illness. Sometimes, the need for intensive treatment necessitates a phase of residential rehabilitation in addition to usual community options. Sustainable recovery is underpinned by more than behavioural stability or sobriety. Modern addiction services promote well-being, increasingly as defined by the patient rather than by politicians, doctors or society. 